\title{
Roots of modern cardiology in Poland
}

\author{
Ryszard W. Gryglewski \\ Department of History of Medicine, Jagiellonian University Medical College, Krakow, Poland
}

\begin{abstract}
The aim of the paper was to present the achievements of Polish physicians in the field of heart diseases in the times when cardiology was still not established as a separate branch of medicine, i.e. in the last decades of the $19^{\text {th }}$ and the opening decades of the $20^{\text {th }}$ centuries. The article is based on results previously delivered in historical works of other researchers and on original texts coming from the era which is the subject of the present report. The review focuses on the main topics of scientific investigation related to heart diseases - the subject of interest for physicians who are depicted herein. It should be stressed that only part of their intellectual heritage could be presented, with only a limited selection of names, articles, or books. Nevertheless, even when narrowed in scope, it shows innovativeness in many aspects of practical and scientific approaches to clinical problems. It also brings to our mind times when the dreams of many have wandered around the independence of one's homeland, dreams which finally came true in 1918. From Adam Raciborski, who was fighting in the November Uprising and then was forced to leave Polish soil, to Andrzej Klisiecki, a soldier of the resurrected Polish army, defending his country against the Bolshevik invasion in 1920, the majority of researchers would take a strong patriotic attitude and work for the benefit of society. When Poland was back on the maps of Europe, they were able to open a new chapter in their scientific research, valuing the treasure of independence.
\end{abstract}

Key words: history of medicine, cardiology, clinical medicine, internal diseases, physiology, electrocardiogram

Kardiol Pol 2018; 76, 11: 1500-1506

\section{INTRODUCTION}

At the turn of the $20^{\text {th }}$ century, cardiology as an independent clinical specialty did not yet exist, but diagnosis and treatment of heart diseases were already topics of interest of many Polish physicians, in particular internists, pathologists, and physiologists. It should be noted that the very first steps towards modern cardiology were taken even earlier, in the first half of the $19^{\text {th }}$ century, when the rudiments of mediate auscultation and percussion methods were firmly established. Among those who made significant contributions in that field was Adam Raciborski (1809-1871), whose Nouveau manuel complet d'auscultation et de percussion, ou application de l'acoustique au diagnostic des maladies (1835) should be remembered as the best textbook devoted to the subject of clinical diagnosis. Originally written in French, it was translated to English, Greek, and German, gaining international recognition. It is worth mentioning that as early as in 1812, a young Vilnius physician, Józef Chrzczonowicz (1790-1823), in his doctoral dissertation Dissertatio inauguralis medica de angore pectoris, presented one of the most precise descriptions at the time of angina pectoris symptoms, which he encountered performing autopsies on the bodies of people who had died of the disease [1].

\section{JÓZEF PAWIŃSKI}

Many researchers consider Józef Pawiński (1851-1925), a chief physician in Infant Jesus Hospital (Szpital Dzieciątka Jezus) and then in Holy Spirit Hospital (Szpital Św. Ducha) in Warsaw, who devoted a great deal of attention to pathology and heart disease therapy, to be the pioneer of modern cardiology in Poland [2-4]. He was an undisputed authority in the field of research on heart defects, with special attention given to those of a congenital nature. In his first strictly scientific paper, Pawiński carefully investigated the problem of the heart's hemisystole, a phenomenon previously described by Ernst Victor von Leyden (1832-1910) [5]. The German physician claimed that it resulted from a characteristic and isolated contraction of the right ventricle. Pawiński's own research led to a different explanation. He could prove that if a premature heart contraction is too weak, it may not cause a pulse wave detectable at the periphery. In conclusion, Pawiński argued that the heart's hemisystole should be connected with the 
bigeminal rhythm, resulting in contractions too weak for peripheral propagation to occur [6].

Pawiński paid much attention to the pathology of myocardial ischaemia, which could be associated with symptoms referred to as angina pectoris. The preliminary report of his investigation was presented for the first time in a paper entitled Zwężenie i zatkanie tętnic wieńcowych serca pod względem fizyologicznym, anatomopatologicznym i klinicznym ("Coronary artery stenosis and occlusion - a physiological, pathological, and clinical view") [7]. The results achieved at that time led to the conclusion that angina pectoris is not always connected with constriction of the coronary arteries, while the most evident consequences of it were ischaemic lesions in the myocardium itself. He also researched the direct and indirect influence of pericarditis as a triggering mechanism of angina pectoris [8], the responses aiming to compensate the symptoms of stenocardia [9] or a possible correlation between septicaemia and angina pectoris [10], to name just a few topics of interest. Finally, he concluded that the term stenocardia is far more adequate than angina pectoris to describe the disease to which he devoted so many years of scientific investigation [11].

The description of a characteristic murmur present in the pulmonary artery should be considered classic today. Based on his own clinical observations, then confronted with the results of an autopsy, Pawiński proved that in some cases of stenosis of the mitral orifice with accompanying ventricular hypertrophy and dilatation of the artery lumen, one can detect a diastolic murmur resulting from relative pulmonary regurgitation in mitral stenosis [12]. The Polish researcher was not aware that five years previously, in 1888, a British physician named Graham Steell (1851-1942) had already described this murmur "as the result of long-continued excess of blood pressure in the pulmonary artery" in patients with mitral stenosis [13]. If we compare both accounts we must admit that the explanation of the murmur mechanism provided by Pawiński was more accurate, which is why it is in fact sometimes called the Steell-Pawiński murmur [4, 14].

Pawiński had significant participation in the diagnosis and classification of cardiac arrhythmias, especially those occurring with valve defects [15]. The Polish physician was known for showing that observed physiological irregularities in the heart's action can be associated with the respiration mechanics in the course of so-called respiratory arrhythmia. For many years he worked on the characteristics of the circadian rhythm of the heart's tones in physiological and pathological conditions [16, 17].

\section{EDWARD KORCZYŃSKI}

In 1887, an incredibly gifted clinician and a talented scientist, Jagiellonian University Professor Edward Sas-Korczyński (1844-1905), published a paper entitled Zator tętnicy wieńcowej serca (Embolia arteriae coronariae cordis) za życia rozpoznany ("Coronary artery embolism [Embolia arteriae coronariae cordis] diagnosed in a living patient") [18]. Carefully studying case reports from the European medical press, he concluded that the majority of them referred to thrombosis, and only a few were connected with embolism. What is more, Korczyński noted the almost complete lack of clinical descriptions while most of the data were obtained from post-mortem autopsies. One female patient of his was hospitalised for eight days, during which regular and detailed examinations were conducted. She died suddenly during the course of a close examination conducted by him during a bedside teaching class. Having properly collected clinical results, he could explain the sudden death as a fatal consequence of coronary artery embolism. He wrote (own translation): "A sudden pain in the precardial region of the heart, so strong that the patient sitting on the bed was knocked down and the change in facial features similar to the one seen in stenocardiac attacks, directed [my] attention on the coronary arteries of the heart" [19]. The autopsy fully confirmed Korczyński's diagnosis. It was the first such intravital diagnosis done on Polish soil and just second to the communication of the Austrian physician Adam Hammer (1818-1878). Unfortunately, Korczyński published his text in Polish, so the impact of his work remained rather limited as far as international research on that subject was concerned [2].

The Polish physician was also a pioneer in the introduction of nitroglycerin to everyday clinical practice when symptoms of angina pectoris occurred, presenting his report two years after the findings of the British pharmacologist William Murrell (1853-1912) were published. In cooperation with Michał Janocha, who conducted a series of auto-experiments, Korczyński was willing to confirm or reject nitroglycerin-induced effects in different diseases. In conclusion, he was able to point to it as a strong substance which quickly abolished typical signs of stenocardiac attack, giving the patient fast relief [20].

\section{WŁADYSŁAW JANOWSKI}

Władysław Janowski (1866-1928), a bacteriologist and an internist who for many years was the head of internal diseases at Infant Jesus Hospital in Warsaw, was interested in various fields of scientific and clinical research exploring the mechanism of atherosclerosis or investigating diagnostic models for arterial blood pressure and the characteristics of pulse changes, to name just a few [21]. His work on different types of arrhythmia was of the highest quality. Janowski's paper on intercostal neuralgia provided a new and useful diagnostic scheme for differentiation of numerous heart diseases [22]. Of clinical importance was his report on the dicrotic pulse in the case of insufficiency of the aortic valve [23] as well as observations conducted on minimal fluctuations in the duration of individual pulse rate waves in normal and pathological conditions [24]. He was precise and modern when making detailed reports on his study of the pulse in connection with blood pressure measurement [25] or when analysing different types of arrhythmia observed in the pulse [26]. Using 
a combined examination of the pulse measurement on the radial artery and jugular vein together with oesophagography (for the pulse rate of the left atrium recorded through the oesophagus), Janowski concluded that in Stokes-Adams disease, disturbances in the electrical conduction system of the heart led to a threefold increase in atrial contractility of the heart if compared with the contraction ratio of the left ventricle [27]. Considering the causes of arteriosclerosis, he concluded that they can be described as mechanical, chemical, or those arising from the nervous system [28]. He also made an important contribution to the proper interpretation of changes in electrocardiogram (ECG) waves. His monograph "Modern methods of the heart examination" was of the highest quality. It was subsequently published in Polish [29] and German [30].

\section{TEODOR DUNIN}

Teodor Dunin (1854-1909) became one of the most important figures in the history of internal diseases in Poland. For many years the head of the Internal Department of Infant Jesus Hospital in Warsaw, he was constantly interested in various internal diseases. Among the main areas of his scientific research were problems concerning the pathological mechanism of malaria, metabolic regulation of uric acid during inflammation, clinical pulmonology, and aetiology of traumatic neurosis, to name just a few [31]. Dunin was the first on Polish soil to study the mechanism of hypertension in patients with atherosclerosis. Working on a group of over 400 patients, he made close observations and precise measurements, which led him to the conclusion that an increase in blood pressure is closely related to disorders of adipose tissue metabolism. He postulated that a low-fat diet can be beneficial because of the absence of hypothetically assumed chemical compounds, which could stimulate the vessel walls, provoking their contraction, which in turn would cause a constant increase in pressure. Additionally, Dunin explained the process of deposition of lipids in the arterial walls in long-term hypertension as a manifestation of a self-defence mechanism against a potential injury of smaller arteries [32]. He is also remembered as a talented and influential teacher. Among his students was Kazimierz Rzętkowski.

\section{KAZIMIERZ RZĘTKOWSKI}

Kazimierz Rzętkowski (1870-1924), a professor at Warsaw University, was deeply involved in research concerning nucleic and protein transformation in the human body, blood alkalinity, and the transformation of chlorides in the organic structures [33]. As part of his scientific programme, Rzętkowski conducted intensive studies on the physiology of cardiac function in different heart diseases, exploring the conditions and mechanism of heart failure with multilevel analysis of chemical changes in the myocardium. When considering functional and morphological changes in the heart, Rzętkowski argued that biochemical and chemical reactions should be closely investigated. He found that the decrease in protein content, the increase in sodium chloride concentration, and electrolyte disturbances were responsible for the loss of the ability of the cardiac muscle to use the energy resources for contraction [34]. It is worth mentioning that even earlier Rzętkowski had performed experiments on rabbits, which led to the development of atherosclerosis of the aorta. Prolonging high blood pressure by provoking it with intravenous adrenaline injections, he purposely exposed the vessel wall to hard conditions, achieving the expected pathological changes. However, he could not determine the background of the physiological mechanism and was confronted with two potential logical explanations. First, that adrenaline could trigger atherosclerosis through its direct, but yet unknown, action on the structure of the vessel wall, or second, that it acted indirectly, damaging the vessel wall by the increase of blood pressure [35]. This issue became the subject of investigation for other researchers: internists Erwin Mięsowicz (1875-1914) and Zenon Orłowski (1871-1948) and pathologists Witold Nowicki (1878-1941) and Joseph S. Hornowski (1874-1923). It was then determined that chronic arterial hypertension provoked by adrenaline is closely connected with atherosclerosis. The findings provided clear evidence that the increase of vascular tone and the vasoconstrictor reactions are important factors involved in the pathophysiology of hypertension [36].

\section{WITOLD EUGENIUSZ OREOWSKI}

Witold Eugeniusz Orłowski (1874-1966) remains one of the best-known personalities in the history of Polish medicine. $\mathrm{He}$ is well remembered for his studies in the field of gastroenterology and nephrology, as well as pulmonology. Having received his education at the Military Medical Academy at Saint Petersburg, Orłowski had the opportunity to have among his teachers the famous scientists Siergiej Botkin and Ivan Pavlov, from whom he learned a modern experimental approach to clinical problems. Beginning his career in Russia, where at the University of Kazan he was appointed an associate professor (1907), and a few years later, a full professor (1913), Orłowski came to Poland after the First World War ended and his homeland gained independence. First, he was appointed as the head of the university clinic in Krakow, and then, in 1925 he moved to Warsaw [36, 37].

Orłowski is regarded as the founder of one of the largest and most influential schools of internal diseases concerned with pathophysiological and biochemical research. He clearly understood the necessity of an interdisciplinary approach to clinical medicine. This led to the foundation of many specialised research and diagnostic laboratories. Orłowski was the first in Poland to establish a metabolic diseases ward. He became the author and co-author of many textbooks and monographs, which marked a new era in teaching and learning internal diseases. His works include those concerned with heart diseases. Of great importance was his "General principles of medical treatment in chronic heart diseases" [38], 
which was the most valued text for teaching cardiology in Poland. In his work on chronic circulatory insufficiency, Orłowski paid special attention to the biochemical reactions occurring in tissues. He was able to show and describe characteristics associated with the pathological changes on haemodynamic and metabolic levels. This led him to point out a systemic nature of this disease, thus questioning Eppinger's theory, which was widely held in those times. Although he could not give a clear explanation of the pathological mechanism itself, Orłowski hypothesised that the cause of chronic circulatory failure was the presence of as yet undetected toxic substances [39].

\section{MŚCIWÓJ SEMERAU-SIEMIANOWSKI}

Heart diseases were an early subject of interest for Mściwój Semerau-Siemianowski (1885-1953), who in 1918 became an assistant professor at the First Department of Internal Diseases at Holy Spirit Hospital in Warsaw. After attending university in Strasbourg, he was assistant to Karel F. Wenckebach (1864-1940) for several years. Wenckebach was one of the leading figures in the field of pathology and physiology of the heart [40]. Under his guidance, Semerau-Siemianowski wrote the first of his many papers devoted to cardiac diseases. In 1914 he published Beiträge zur Lehre vom Pulsus paradoxus, giving the very first description of paroxysmal atrial fibrillation (AF) based on ECG examination. In the following years, Semerau-Siemianowski made further contributions to the research on $\mathrm{AF}$, presenting a clear picture of its paroxysmal form. In the following years he focused on accurate diagnostic methods that could offer a precise tool for ECG differentiation of arrhythmia connected with AF. The results then achieved served Semerau-Siemianowski to develop an original classification of arrhythmia given in the five topological groups [41-43]. In 1923 Semerau-Siemianowski presented work for his postdoctoral degree habilitation, in which he showed the effects of different drugs on both heart ventricles, describing pathophysiological conditions of bigeminy and polygeminy. He observed that under such conditions the spontaneously emerging reaction of the ventricles was similar to ventricular fibrillation [44]. He was also the first to describe hyposphyxia paroxysmalis (shock-like symptoms with collapse), which is often named after him in the medical literature [37, 45, 46]. Extensive research on cardiac conduction disorders in atherosclerosis, diphtheria, and rheumatic disease brought to life many important conclusions. In the 1920s he described the pathogenesis, symptoms, clinical course, and treatment of haemorrhagic diathesis [37].

Semerau-Siemianowski was constantly interested in the pharmacological treatment of heart diseases, with special attention given to the effects of various drugs on the autonomous nervous system of the heart. He pioneered the usage of physostigmine. In his brilliant work with Klementyna Rachon, he gave clear evidence that quinidine should not be administered when circulatory insufficiency is accompanied by chronic AF [47]. It is worth mentioning that Semerau-Siemianowski investigated the clinical symptoms of coronary heart disease and coined the Polish term dławica piersiowa, which replaced the Latin expression for angina pectoris $[37,48]$.

\section{NAPOLEON NIKODEM CYBULSKI}

Napoleon Nikodem Cybulski (1854-1919), professor of physiology at Jagiellonian University, was one of the most brilliant scientists of his time. In cooperation with Władysław Szymonowicz, he discovered a potent biological factor produced in the adrenal glands, which strongly constricted blood vessels and elevated blood pressure, becoming a milestone in the history of modern sciences. Polish researchers named it suprarenin (nadnerczyna in Polish), which in fact, as was later established, came to be known as adrenaline [49].

Cybulski pioneered electrocardiography in Poland [50]. He considered ECG to be an excellent method for studying physiological phenomena in both normal and experimental conditions. In one of his early works, Cybulski concluded that electrical phenomena are probably caused by changes occurring during metabolism, accompanying all anabolic and catabolic processes; the former he associated with increases of potential, and the latter, with decreases. An equilibrium between anabolic and catabolic processes resulted in the balancing of potentials. It may be stated that it was in fact a biochemical concept for the regulation of the electrical processes occurring in a living organism [50, 51]. In cooperation with Józef Surzycki, Cybulski conducted a series of experiments to establish the ECG characteristics of abnormal heart function caused by various diseases [52].

\section{MARIAN EIGER}

Marian Eiger (1873-1939) studied medicine at the universities in Warsaw, Dorpat (Tartu), and Moscow. He then travelled to Berlin where he worked under the guidance of the famous physicians Eduard Mendel and Albert Fraenkel. From 1907 he worked at Infant Jesus Hospital in Warsaw, receiving his PhD two years later in Moscow. Eiger, already interested in basic sciences, had the opportunity to take the position of assistant to Cybulski [53]. Under his supervision between 1910 and 1914 , the young researcher conducted scientific research focused on the physiology of the heart. One topic of interest was to assess the influence of general anaesthesia on ECG measurements in experimental conditions. In cooperation with Cybulski Eiger proved that in an animal model, anaesthesia causes significant changes in the ECG curve. However, as the scientists stated, future observations in humans were crucial for further research [50]. Their report ends with the following statement (own translation): "One conclusion can undoubtedly be made on the basis of this research, namely that the electrocardiographic curve may serve as an objective criterion, as a test for the condition of the heart, both before and during anaesthesia." [50, 54].

Eiger conducted a series of experiments on both isolated and non-isolated animal hearts, mainly those of frogs and 
dogs. He used the results of experiments conducted on fish, oyster, and crayfish hearts with single atria and single ventricles as material for comparison. In addition to complete hearts, Eiger also conducted experiments on prepared hearts - atria without ventricles, beating venous sinuses in frogs after previous amputation of the atria and ventricles, or beating outlets of the venae cavae. Eiger opposed the widely accepted view that $\mathrm{Q}, \mathrm{R}, \mathrm{S}$, and $\mathrm{T}$ waves should be associated with the expansion of electrophysiological phenomena in ventricular structures alone. He demonstrated that $\mathrm{Q}, \mathrm{S}, \mathrm{T}$, and $\mathrm{P}$ waves are visible in the ECG recordings of amputated and non-amputated atria of isolated and non-isolated frog hearts. In a beating bulb of the main artery and venous sinus, it was possible to register the characteristic R, S, and T waves. The final results of Eiger's research were published first in Polish, then in German [50, $55,56]$. In subsequent papers, he analysed the ECG curve as an algebraic sum of cardiac action currents, conducting his experiments on animals and comparing the results with human ECG recordings. He once again revised the origin of the waves, reaching the conclusion that there is a different active state source for the $T$ wave than in the case of the $\mathrm{R}$ and $\mathrm{S}$ waves. Moreover, he stated that $\mathrm{R}$ and $\mathrm{S}$ constitute the expression of the first, two-phase active state $[50,57,58]$. Multiple examinations were conducted on a single patient with exudative endocarditis, demonstrating that the consecutive ECGs changed together with the patient's gradual recovery. Therefore, the relation between heart function and ECG readings was considered to be confirmed.

The physiology of the heart remained one of the main areas of Eiger's scientific interests throughout his career. While holding a professorial chair at Stefan Batory University in Vilnius, he made an important contribution to solving the problem of cardiac automatism, hypothesising that specific ganglion cells located in the vicinity of the endocardium are the natural source of this mechanism $[59,60]$.

\section{JÓZEF LATKOWSKI}

Józef Latkowski (1873-1948), who became a professor of internal medicine in Krakow, also showed great interest in the opportunities offered by electrocardiography. He was responsible for establishing ECG as the obligatory method in the diagnosis of heart disease. In 1912, Latkowski presented a clear ECG picture of dextrocardia [61]. Based on the results obtained earlier by Cybulski, he confirmed that, in the case of dextrocardia, electrical activity occurred before the actual mechanical action of the myocardium [50]. He is also remembered as the first in Poland to publish a paper in which he presented the ECG recording in pericardial adhesions [62].

\section{ALEKSANDER JANUSZKIEWICZ}

As far as internists are concerned, Aleksander Januszkiewicz (1872-1955), a professor of internal diseases at Stefan Batory University in Vilnius, deserves particular attention [63]. His most important studies on cardiology were published in the late 1920s and 1930s. Januszkiewicz was investigating, among other things, heart arrhythmia and coronary attack as the consequence of long-term coronary arterial disease. The most important paper, Nadciśnienie Tętnicze (Hypertensio). Referat programowy VIII Zjazdu Towarzystwa Internistów Polskich, was published in Polish in 1929 [64], with a detailed analysis of the causes and possible mechanism of arterial hypertension. Januszkiewicz revised all of the then known theories concerning hypertension, arguing that among them a new category of the disease should be distinguished, namely primary (essential) hypertension. Gathering hundreds of clinical reports and using statistical methods, he was able to present a very modern monograph of great practical and scientific value [63].

\section{ANDRZEJ KLISIECKI}

The physiology and pathology of the blood circulation system remained the leading research topic of Andrzej Klisiecki (1895-1975) throughout his academic and scientific career, first at the University of Lviv and then at Lviv Veterinary Academy [65]. As a student of Cybulski, Klisiecki became deeply interested in the modifications of the photohaemotachometer, an apparatus for the measurement of blood flow in vessels, invented by his professor in 1885. In a matter of years, he made an important contribution to the technical sophistication of the apparatus itself [66]. When using it Klisiecki was able to determine the correct mathematical formula for the blood flow velocity [67]. His research based on the calculations done with Cybulski's manometer delivered firm data for the presence of systolic and dicrotic speed waves in the aorta. The breath waves, which thus far were known to occur only in the peripheral arteries, were also detected and described. The speed waves analogous to the so-called Traube-Hering waves in the recordings of arterial blood pressure were confirmed as well $[14,68]$. Research conducted in the 1930s in cooperation with Wiesław Hołobut focused on the aetiology and pathogenesis of histamine shock. The evidence for disturbed left ventricular function, resulting in a fall in arterial blood pressure, was presented in a separate paper that was highly valued for its content [69].

\section{CONCLUSIONS}

In conclusion, it can be said that at the turn of the $20^{\text {th }}$ century and the first few decades that followed, cardiological issues were a constant subject of interest to a number of practitioners as well as researchers. From what has been said, the most influential personalities in that field were Pawiński and later Semerau-Siemianowski as we look upon clinical medicine. The research done by Cybulski, Eiger, and Klisiecki was of the utmost importance for cardiac physiology and diagnostics. Biochemical and metabolic levels of analyses (Orłowski, Rzętkowski) or combined diagnostic methods (Korczyński, Janowski, Latkowski) should be seen as an important basis for modern cardiology, encompassing both scientific research and 
clinical practice. The monograph by Januszkiewicz on hypertension could be named as a classic text in internal diseases.

It should not be forgotten that the presented achievements took place when the history of the Polish nation was reaching a turning point, which cumulated with regained independence in 1918. Patriotism and strong conviction to offer one's talents and work for the benefit of society was a typical attitude among the majority of researchers. Thus, science became an important part of the modern history of Poland, with scientists devoting their time and energy not only to professional affairs. Semerau-Siemianowski donated his precious numismatic collection to the National Museum, receiving the title of honorary custodian, while Eiger was an active member of the Society of Friends of Science in Vilnius, to give just two examples. They both truly became, as did all, the intellectual and cultural elite of our country and will be remembered for their passion and dedication to cultivating its traditions and future.

\section{Conflict of interest: none declared}

\section{References}

1. Skalski JH. Myocardial infarction and angina pectoris in the history of Polish medicine. Part 1. Discovery and understanding of the disease. Pol Arch Med Wewn. 2008; 118(4): 243-247, doi: 10.20452/pamw.374, indexed in Pubmed: 18575426.

2. Skalski JH. Myocardial infarction and angina pectoris in the history of Polish medicine. Part 2. Diagnosis and early attempts at treatment: the 19th and 20th centuries. Pol Arch Med Wewn. 2008; 118(4): 248-254, indexed in Pubmed: 18575427.

3. Ruciński Z, Skalski JH, Śródka A. Kardiologia w okresie zaborów. In: Kuch J, Śródka A ed. Dzieje kardiologii w Polsce na tle kardiologii światowej. [Polish] PWN, Warszawa. 2004: 167-228.

4. Zamachowska M. Pawiński Józef In: Orłowski B. (ed.) Polski wkład w przyrodoznawstwo i technikę. IHN PAN — IPN. Warszawa. 2015; 3: 265-266.

5. Pawiński J. O tak zwanym połowicznym skurczu serca. Hemisystolia cordis (Leyden). [Polish] Gaz Lek. 1882; 17. Warsaw [seperate print].

6. Zwolski S. Józef Pawiński (1851-1925). In: Skalski JH, Gryglewski RW ed. Zasłużeni dla medycyny Europejczycy związani z polską ziemią [Distinguished in their services to medicine Europeans from Polish soil]. Termedia, Poznań; 2009: 190-196.

7. Pawiński J. Zwężenie i zatkanie tętnic wieńcowych serca pod względem fizyologicznym, anatomopatologicznym i klinicznym [Polish]. Gaz Lek. 1883; 18 (35-38): 659-667, 683-692, 705-714, 725-735.

8. Pawiński J. O wpływie (suchego) zapalenia osierdzia na powstawanie stenokardii i dychawicy sercowej. [Polish] Gaz Lek. 1897; 32 (1-5): 5-10, 41-47, 70-76, 95-102, 127-136.

9. Pawiński J. O samopomocy organizmu w dusznicy bolesnej (angina pectoris). [Polish] Gaz Lek. 1899; 34 (1-5): 1-6, 39-45, 68-74, 89-96, 118-125.

10. Pawiński J. Dusznica bolesna przy zakażeniu septycznym. [Polish] Gaz Lek. 1903; 23 (40-41): 933-940, 968-973.

11. Pawiński J. Angina pectoris w świetle przeszłości. [Polish] Pam Tow Lek Warsz. 1908; 54: 14-57.

12. Pawiński J. O względności niedomykalności zastawek półksiężycowatych tętnicy płucnej przy zwężeniu ujścia żylnego lewego. [Polish] Gaz Lek. 1893; 28(20): 514-525.

13. Steell G. The murmur of high pressure in the pulmonary artery. Med Chron. 1888; 9: 182.
14. Skalski JH, Kuch J. Polish thread in the history of circulatory physiology. J Physiol Pharmacol. 2006; 57 (Suppl 1): 5-41, indexed in Pubmed: 16766800.

15. Pawiński J. Badania kliniczne nad arytmią serca w ogóle, a w szczególności przy wadach zastawek. [Polish] Pam Tow Lek Warsz 1883; 79: 247-295, 400-587, 684-755.

16. Pawiński J. O rytmie wahadłowym tonów serca i jego stosunku do rytmu galopowego. [Polish] Gaz Lek. 1890; 25(49): 967-972.

17. Pawiński J. Powstanie i znaczenie kliniczne rytmu cwałowego (galopu). [Polish] Gaz Lek. 1906; 26 (22-25):569-578, 604-610, 634-638, 655-657.

18. Gryglewski RW. [Edward Korczyński]. [Polish] Pol Arch Med Wewn. 2007; 117(4): 76-78, indexed in Pubmed: 17722480.

19. Korczyński E. Zator tętnicy wieńcowej serca (embolia arteriae coronoriae cordis) za życia rozpoznany. [Polish] Przeg Lek 1887; 26 (1, 3-5): 20-21, 41-43, 57-59, 75-76.

20. Korczyński E. Kilka słów o działaniu fizyologicznem i o zastosowaniu leczniczem nitrogliceryny (na podstawie doświadczeń wykonanych wspólnie z Michałem Janochą). [Polish] Pam Tow Lek Warszaw. 1881; 4: 609-628.

21. Śródka A. Uczeni polscy XIX-XX stulecia. [Polish] Ares Warszawa. 1995; 2: 98-99.

22. Janowski W. O nerwobólu międzyżebrowym (neuralgia intercostalis) głównie ze stanowiska skarg chorego. [Polish] Przeg Lek 1906; 45 (41-46): 679-685, 708-709, 724-726, 736-739, 750-752, 760-762.

23. Janowski W. O tętnie dwubitnem przy niedostateczności zastawek aorty. [Polish] Now Lek. 1906; 18(10): 413-418.

24. Janowski W. O minimalnych wahaniach w trwaniu poszczególnych fal tętna w stanach prawidłowych i patologicznych. [Polish] Przegl Lek. 1907; 46 (15-16): 189-191, 202-204.

25. Janowski W. Dyagnostyka funkcjonalna serca i naczyń. [Polish] Now Lek. 1907; 19 (10-12): 525-536, 600-613, 658-669.

26. Janowski W. O różnych postaciach niemiarowości tętna z dzisiejszego punktu widzenia. [Polish] Gaz Lek. 1911; 31 (39-44): 1057-1064, 1087-1094, 1117-1124, 1142-1149, 1165-1170, 1194-1198.

27. Janowski W. Przyczynek do znaczenia krzywych otrzymywanych przez przełyk z lewego przedsionka serca dla dokładnego rozpoznania choroby Stokesa-Adamsa oraz parę uwag o bradykardii. [Polish] Medycyna 1908; 43 (19-20): 449-454, 478-481.

28. Janowski W. Ciśnienie krwi i ciśnienie tẹtna w stwardnieniu tętnic oraz w zapaleniu nerek. [Polish] Gaz Lek. 1914; 34 (10-12): 257, 288, 313.

29. Janowski W. Współczesne metody badania serca. [Polish] Warszawa. 1910.

30. Janowski W. Die funktionale Herzdiagnostik. Berlin. 1910.

31. Śródka A. Uczeni polscy XIX-XX stulecia. [Polish] Ares. Warszawa. 1994; 1: 412-413.

32. Dunin T. Materiały do nauki o stwardnieniu tętnic. [Polish] Gaz Lek. 1903; 23 (48-50): 1114-1117, 1144-1147, 1163-1172.

33. Śródka A. Uczeni polscy XIX-XX stulecia. [Polish] Ares. Warszawa. 1997; 3: 612-614.

34. Rzętkowski K. O zmianach chemicznych w mięśniu sercowym w chorobach serca. [Polish] Przegl Lek. 1910; 49(1): 1-7.

35. Rzętkowski K. Miażdżyca aorty, wywołana u królików przy pomocy dożylnych wstrzykiwań adrenaliny. [Polish] Gaz Lek. 1904; 25(22): 524-528.

36. Śródka A. Kardiologia w okresie międzywojennym in: Kuch J, Śródka A ed. Dzieje kardiologii w Polsce na tle kardiologii światowej. [Polish] PWN. Warszawa. 2004: 230-249.

37. Supady J. Distinguished Polish internists: Witold E. Orłowski and Mściwój M. Semerau-Siemianowski. Pol Arch Med Wewn. 2013; 123(7-8): 347-349, indexed in Pubmed: 23974288. 
38. Orłowski WE. Ogólne zasady postępowania leczniczego w przewlekłych chorobach serca. [Polish] Now Lek. 1927; 39(4): $121-126$

39. Orłowski WE. Patogeneza przewlekłej niewydolności układu krążenia ze szczególnym uwzględnieniem teorii obwodowomięśniowej Eppingera. [Polish] Pol Arch Med Wewn. 1930; 8(2): 649-700.

40. Ostrowska T. Semerau-Siemianowski Mściwój. [Polish] PSB 1995-1996; 36: 223-226.

41. Semerau-Siemianowski M. O niemiarowości ciągłej tętna jako głównym objawie migotania przedsionków. [Polish] Now Lek. 1916; 28(3-4): 127-135.

42. Semerau-Siemianowski M. Die Flimmerarrhythmie. Ergebnisse der Inneren Medizin und Kinderheilkunde. 1921; 19: 124.

43. Semerau-Siemianowski M. Kliniczne znaczenie migotania przedsionków. [Polish] Gaz Lek. 1919; 54(33-34): 385-389, 401-404.

44. Semerau-Siemianowski M. O czynności samoistnie bijących komór sercowych u człowieka: studium farmakologiczne i patologiczno-fizjologiczne. [Polish] Altenberg. Lwów. 1923.

45. Semerau-Siemianowski MO. nerwicach sercowo-naczyniowych na tle niedomogi wewnątrzwydzielniczej gruczołów płciowych. [Polish] Pol Arch Med Wewn. 1927; 5(4): 737-756.

46. Gryglewski RW. Mściwój Semerau Siemianowski 1885-1953 in: Baraniewski W, Tygielski W, Wróblewski AK ed. Portrety uczonych: Profesorowie Uniwersytetu Warszawskiego po 1945 roku. [Polish] Wydawnictwa Uniwersytetu Warszawskiego. Warszawa. 2016: 89-97.

47. Semerau-Siemianowski M, Rachoń K. O leczeniu chinidyną niemiarowości zupełnej na tle migotania przedsionków. [Polish] Pol Arch Med Wewn. 1926; 4(1): 5-40.

48. Semerau-Siemianowski M. Klinika dławicy piersiowej. [Polish] Pol Arch Med Wewn. 1933; 11(3): 371-464.

49. Pawlik WW, Konturek SJ, Bilski R. Napoleon Cybulski-Polish pioneer in developing of the device for measuring blood flow velocity. J Physiol Pharmacol. 2006; 57 Suppl 1: 107-118, indexed in Pubmed: 16766802.

50. Gryglewski RW. The origins of electrocardiography in Poland. Kardiochir Torakochirurgia Pol. 2015; 12(2): 184-189, doi: 10.5114/kitp.2015.52868, indexed in Pubmed: 26336508.

51. Cybulski N. Kilka uwag o elektrokardyogramach na podstawie własnych doświadczeń. [Polish] Gaz Lek. 1910; 45, 30(17-18): 382, 405-386, 410.

52. Cybulski N, Surzycki J. Zmiany elektrokardiograficzne wywołane obecnością cieczy w worku osierdziowym. [Polish] Przeg Lek. 1912; 51(32): 499-502.

53. Sródka A. Marian Eiger 1873-1939. Acta Physiol Pol. 1987; 38(3): 225-236, indexed in Pubmed: 3321904.

54. Cybulski N, Eiger M. O elektrokardyogramach przy rozmaitych rodzajach uśpienia. [Polish] Med Kron Lek. 1911; 45(49): 1140-1145.

55. Eiger M. Podstawy fizyologiczne elektrkardyografii. Cz. I. Kształt zasadniczy krzywej elektrokardiograficznej i wyjaśnienie załamków krzywej. [The Basic shape of the Electrocardiographic Curve and the Explanation of Deflection Forming]. Rozp Wydz Mat-Przyr AU. Kraków 1911; ser. B 11: 373-441,

56. Eiger M. Die physiologischen Grundlagen der Elektrokardiographie. Pflüger's Archiv für die Gesamte Physiologie des Menschen und der Tiere. 1913; 151(1-3): 1-51, doi: 10.1007/bf01681138.

57. Eiger M. Krzywa elektrokardiogramu jako wyraz sumy algebraicznej prądów czynnościowych w sercu jednokomorowem i dwukomorowem (Podstawy fizyologiczne elektrkardyografii. Cz. II). [The Electrographic Curve as an Expression of the Algebraic Sum of Action Currents of the Mono- and Biventricular Heart]. Rozp Wydz Mat-Przyr AU. Kraków. 1914; B14(2): 203-247.

58. Eiger M. Das Elektrokardiogramm als Ausdruck der algebraischen Summe (bzw. Resultante) der Aktionsströme des einkammerigen und zweikammerigen Herzens. Pflüger's Archiv für die Gesamte Physiologie des Menschen und der Tiere. 1915; 162(7-10): 433-488, doi: 10.1007/bf01681651.

59. Eiger M. Les ganglions et les cellules nerveuses sous endocardioques: leur rôle dans l'automatisme du coeur. Zurich. Ed. Art. Instit. Orell Füssli. 1923 (Extr. Arch Suisses Neurol Psychiat 13).

60. Eiger M. O zwojach i komórkach nerwowych podwsierdziowych oraz o ich roli fizjologicznej. [Polish] Med Dośw Społ. 1930; 11: 88-103.

61. Latkowski J. Sprawozdanie z posiedzenia Towarzystwa Lekarskiego Krakowskiego z dnia 31 stycznia 1912 roku. [Polish] Przeg Lek. 1912; 51(8): 145 .

62. Latkowski J. O zmianach elektrokardiogramu przy zrostach osierdzia z otoczeniem. [Polish] Pol Gaz Lek. 1932; 11(40): 721-724

63. Krupa-Wojciechowska B, Bandosz P. Prof. dr med. Aleksander Januszkiewicz (1872-1955). [Polish] Nadciśn Tętnicze. 2002; 6(4): 235-238.

64. Januszkiewicz A. Nadciśnienie Tętnicze (Hypertensio). Referat programowy VIII Zjazdu Towarzystwa Internistów Polskich. [Polish] Pol Arch Med Wewn. 1929; 7: 3-89.

65. Śródka A. Uczeni polscy XIX-XX stulecia. [Polish] Ares. Warszawa. 1995; 2: 213-214.

66. Klisiecki A. Teoretyczne zbadanie kaniuli fotohemotachometru Cybulskiego w zastosowaniu do mierzenia szybkości cieczy. [Polish] Arch Tow Nauk we Lwowie. 1925; 3(15): 347-362.

67. Klisiecki A. On the blood flow and the blood pressure in arteries. Bullet l'Acad Pol Sci, Lettres Cracoviae, Imprimerie de l’Universite. 1930; B(1-2): 1-77.

68. Klisiecki A. Szybkość krążenia w tętniczym układzie krwionośnym oraz wpływ sprężystości jego ścian na ruch krwi. [Polish] Arch Tow Nauk we Lwowie. 1928; 4(7): 77-146.

69. Klisiecki A, Holobut W. Die linke Herzkammer als Herdsitz des Histaminschocks. Naunyn-Schmiedebergs Archiv für Experimentelle Pathologie und Pharmakologie. Arch Exp Path Pharmacol. 1937; 186(1): 57-77, doi: 10.1007/bf01861777.

Cite this article as: Gryglewski RW. Roots of modern cardiology in Poland. Kardiol Pol. 2018; 76(11): 1500-1506, doi: 10.5603/KP.a2018.0199. 